\title{
Section X: Civil Aviation and Civilian Airliners
}

\section{Rule 87}

(a) During an armed conflict, whether international or non-international, States are entitled to restrict or prohibit entry into their national airspace.

\section{Commentary}

1. The Rules in the present Section apply to States and not to non-State actors in a non-international armed conflict (NIAC). That is to say, the Rules of this Section other than Rule 90 (b) do not apply to non-State organised armed groups involved in a NIAC.

2. States have complete and exclusive sovereignty over the airspace above their land and sea territory. ${ }^{1}$ This is reflected in both treaty ${ }^{2}$ and customary international law. ${ }^{3}$

3. This Rule also applies to entry by a military aircraft into the national airspace of a co-belligerent.

\footnotetext{
1“Air" or "airspace" is defined in the AMW Manual Rule (1)(a), see chapter "Section I: Outer Space", fn. 1, as "the air up to the highest altitude at which an aircraft can fly and below the lowest possible perigee of an earth satellite in orbit. Under international law, airspace is classified as either national airspace (that over the land, internal waters, archipelagic waters, and territorial seas of any State) or international airspace (that over contiguous zones, exclusive economic zones, the high seas, and territory not subject to the sovereignty of any State)."

${ }^{2}$ See 1944 Convention on International Civil Aviation (Chicago Convention), ICAO Doc. 7300/9, Articles 1 and 2.

${ }^{3}$ Military and Paramilitary Activities in and against Nicaragua (Nicaragua v. United States of America). Merits, Judgment. I.C.J. Reports 1986, page $14 \mathrm{ff}$., at page 128, para. 251: "The principle of respect for territorial sovereignty is also directly infringed by the unauthorized overflight of a State's territory by aircraft belonging to or under the control of the government of another State."
} 
4. Article 3(c) of the 1944 Chicago Convention on International Civil Aviation (Chicago Convention) states: "No state aircraft of a contracting State shall fly over the territory of another State or land thereon without authorization by special agreement or otherwise, and in accordance with the terms thereof."

5. Article 89 of the Chicago Convention sets forth: "In case of war, the provisions of this Convention shall not affect the freedom of action of any of the Contracting States affected, whether as belligerents or as neutrals. The same principle shall apply in the case of any Contracting State which declares a state of national emergency and notifies the fact to the Council."4 The State should however avoid discriminating between aircraft of its own, neutral or allied registration and ownership when limiting access to its airspace. ${ }^{5}$

6. As regards transit and landing rights of scheduled air services, i.e. services granted access to foreign airspace under international agreements other than the Chicago Convention itself, their application to armed conflicts would be regulated by the relevant agreement, rather than Article 89 of the Chicago Convention.

(b) Subparagraph (a) is without prejudice to the rights of transit passage above international straits and of archipelagic sea lanes passage.

\section{Commentary}

1. Generally speaking, neutral States bordering international straits may not suspend, hamper or otherwise impede the right of transit passage. ${ }^{6}$

2. Neutral warships, auxiliary vessels, and military and state aircraft may exercise the rights of passage provided by general international law through, under and over belligerent international straits and archipelagic waters. The neutral State should, as a precautionary measure, give timely notice of its exercise of the rights of passage to the belligerent State.

3. Neutral States may not suspend, hamper or otherwise impede the right of transit passage nor the right of archipelagic sea lanes passage. ${ }^{7}$

\section{Rule 88}

During an international armed conflict:

(a) Belligerent military aircraft are prohibited from entering neutral national airspace.

\footnotetext{
${ }^{4}$ Chicago Convention, Article 9 (a) and (b), see fn. 2. See also ibid., Annex 2 Rules of the air, page 3-1 (Article 3-1-10). A similar right to limit the use of airspace in "areas of active hostilities or of military occupation, and in time of war along the supply routes leading to such areas" is found in the 1944 International Air Services Transit Agreement, UNTS, vol. 84, page 389, Article 1.

${ }^{5}$ Chicago Convention, see fn. 2, Article 9.

${ }^{6}$ UNCLOS, see chapter "Section IV: Unmanned Maritime Systems", fn. 3, Articles 38 and 44.

${ }^{7}$ Ibid. Articles. 53 and 54.
} 


\section{Commentary}

1. This Rule is based on the customary law of neutrality as referred to in paragraph 1 of the Commentary to Rule 18. Minor intrusions into neutral airspace occur from time to time, and are usually not challenged, but they do not call into question the general applicability of the Rule.

2. This Rule is subject to the power of the UN Security Council to exclude the application of the neutrality principle by virtue of a binding provision.

(b) Subparagraph (a) is without prejudice to the rights of transit passage above international straits and of archipelagic sea lanes passage.

\section{Commentary}

1. See the Commentary to Rule 87 (b).

(c) Neutral States have a duty to prevent or terminate the violation of their national airspace by belligerent military aircraft.

\section{Commentary}

1. This Rule is based on the customary law of neutrality as reflected in the Commentary to Rule 88 (a) and in Article 8 of the 1907 Hague Convention XIII on Neutrality in Naval War.

2. The Group of Experts agreed with the statement made in Rule 168 (b) of the AMW Manual: "If the use of the neutral territory or airspace by a Belligerent Party constitutes a serious violation, the opposing Belligerent Party may, in the absence of any feasible and timely alternative, use such force as is necessary to terminate the violation of neutrality."

(d) If a belligerent military aircraft has been forced to land, the crew must be interned for the duration of the armed conflict.

\section{Commentary}

1. This Rule is based on article 11 of the 1907 Hague Convention V.

\section{Rule 89}

Civil aviation may be prevented from using the airspace covered by a no-fly zone (within belligerent national airspace) or by an exclusion zone (within international airspace). 


\section{Commentary}

1. Restrictions in aviation may take the shape of no-fly zones or exclusion zones. ${ }^{8}$ As stated in Rule 60 in the AMW Manual, "civilian airliners (whether enemy or neutral) ought to avoid entering a no-fly or an "exclusion zone". However, "they do not lose their protection merely because they enter such areas." "9

2. This Rule must be seen in relation to Rule 96 of this Manual, which urges civilian airliners to avoid areas of hazardous military activity.

3. Civil aviation may be prohibited from entering such zones if and to the extent that the Security Council has rendered a decision to that effect in the exercise of its powers under Chapter VII of the Charter of the United Nations.

\section{Rule 90}

(a) For the purposes of this Section, "civilian aircraft" means any aircraft that is not used in military, customs or police services of a State.

\section{Commentary}

1. This definition is based on Article 3(b) of the 1944 Chicago Convention.

2. The reference to the "services of a State" excludes private security and other functions.

(b) Civilian aircraft may not be attacked unless they qualify as lawful targets. Any attack on such aircraft is subject to the applicable principles and rules of LOAC.

\section{Commentary}

1. For general remarks on when objects that would ordinarily be considered civilian objects become military objectives, see paragraph 3 of the Commentary to Rule 10.

2. The principle of proportionality is addressed in general in paragraph 1 of the Commentary to Rule 11.

3. Particular considerations may arise with regard to civilian aircraft, similar but not equal (in gravity) to those that arise with regard to civilian airliners, see Rule 91 (b) with Commentary.

\section{Rule 91}

(a) "Civilian airliner" means a civilian aircraft identifiable as such and engaged in carrying civilian passengers in scheduled or non-scheduled service.

\footnotetext{
${ }^{8}$ Dealt with in the AMW Manual, see chapter "Section I: Outer Space", fn. 1, Section P.

${ }^{9}$ See also the San Remo Manual, see chapter "Section II: Cyber Operations", fn. 29, para 72.
} 


\section{Commentary}

1. This definition is based on the definition made in the AMW Manual Article (1) (i).

(b) Civilian airliners are civilian objects and entitled to particular care in terms of precautions.

\section{Commentary}

1. For general remarks with regard to the duty to take feasible precautions, see paragraph1 of the Commentary to Rule 14.

2. As stated in the Commentary on the AMW Manual, the precautionary measures of identifying the object as a lawful target "must be meticulously observed" by those attacking this category of aircraft ${ }^{10}$; i.e. airliners are entitled to "particular care in terms of precautions". 11 This particular care would seem to follow from the aircraft's importance to international air navigation and the risks to which "innocent [civilian] passengers" are exposed where an armed conflict takes place. $^{12}$ The vulnerability of the aircraft and the possibility of it carrying a large number of passengers - typically civilians - argues for additional protection. ${ }^{13}$

3. There appears to be some reluctance to acknowledge that civilian airliners (like passenger ships) are entitled to particular care insofar as precautions in attacks are concerned. However, the Group of Experts believes that-in light of general acceptance of this notion in the San Remo Manual as well as the AMW Manualit is appropriate to recognize that civilian airliners (like passenger ships) are entitled to supplementary protection.

(c) The mere fact that a civilian airliner is carrying some enemy military personnel, equipment, or supplies together with civilian passengers does not deprive it of its entitlement to particular care in terms of precautions.

\section{Commentary}

1. When a civilian airliner, which is supposed be engaged in carrying civilian passengers, carries enemy military personnel, it becomes a military objective by

\footnotetext{
${ }^{10}$ Commentary on the AMW Manual, see chapter "Section I: Outer Space", fn. 1, page 156 (Commentary to Rule 58).

${ }^{11}$ Commentary on the AMW Manual, ibid, page 31ff. (Commentary to Rule 1(i)), 137 (introductory Commentary to Rule 40), 155 (Rule 58) and 156 (Commentary to Rule 58). San Remo Manual, see chapter "Section I: Outer Space", fn. 29, page 92 (Commentary to para 13(m)).

${ }^{12}$ Commentary on the AMW Manual, see chapter "Section I: Outer Space", fn. 1, page 31 (Commentary to Rule 1(i)).

${ }^{13}$ As mentioned as one of two conflicting views in Commentary on the AMW Manual, ibid, page 155 (Commentary to Rule 58), see chapter "Section I: Outer Space”, fn. 1.
} 
use. However, attack of a civilian airliner can only be considered in the most extreme circumstances and in compliance with the proportionality rule, bearing in mind that civilian airliners are entitled to particular care in terms of precautions.

2. In some instances, the presence of fewer yet key enemy military personnel—such as Generals or other high ranking officers in command with significant influence over on-going hostilities - may turn the airliner into a lawful target. Even then, proportionality must always be borne in mind (see Rule 90(b)).

(d) If intercepted within a no-fly or an exclusion zone, civilian airliners continue to be entitled to particular care in terms of precautions.

\section{Commentary}

1. With regard to interception, see Rule 92 with accompanying Commentary.

\section{Rule 92}

Upon reasonable grounds, civilian airliners are liable to interception and inspection at a sufficiently safe airfield, subject to the following:

\section{Commentary}

1. The phrase "sufficiently safe" is relative and must be assessed under the circumstances ruling at the time, whereas the phrase "reasonable grounds" may, e.g., refer to suspicion that a civilian airliner is carrying contraband. ${ }^{14}$

(a) During an international armed conflict, interception may be exercised by belligerent military aircraft anywhere outside neutral national airspace.

\section{Commentary}

1. This Rule is based on customary international law as also expressed in the AMW Manual Rule 137.

(b) During a non-international armed conflict, interception may be exercised only by the State Party to the armed conflict and exclusively within its national airspace. If, in extraordinary situations, the respective aircraft is present in international airspace, such interception should be exercised only in the vicinity of that State's national airspace.

\footnotetext{
${ }^{14}$ The due regard to safety norm is also expressed in the guidelines by ICAO: International Civil Aviation Organization, Manual concerning Interception of Civil Aircraft (2nd ed. 1990), ICAO Doc. $9433-\mathrm{AN} / 926$.
} 


\section{Commentary}

1. The limitation on interception laid down in this Rule is based on general international law which makes no allowance in non-international armed conflict for the exercise of belligerent rights against aircraft of foreign nationality, and on the concern for the safety of civil aviation in international airspace.

2. An extraordinary situation might be when there is reason to believe that a hijacked airliner will be used as a suicide bomber. Any action against such aircraft would be based on the right to self-defence.

3. The term "vicinity" should be interpreted in light of the prevailing circumstances.

\section{Rule 93}

Refusal to obey an order to land or to change course may render a civilian airliner a lawful target.

\section{Commentary}

1. Civilian airliners are obliged to comply with an order issued by a State party to a conflict to land or to change course. According to customary international law, non-compliance with such orders may render a civilian airliner a military objective.

2. This is based on the San Remo Manual paragraphs 63 and 70 and the AMW Manual Rule 27(d) and 63(e).

\section{Rule 94}

The responsibility of States that provide air-traffic services for the safety of civil aviation remains intact during an armed conflict.

\section{Commentary}

1. The obligation to provide air navigation facilities for the purpose of international air navigation is found in Article 28 of the Chicago Convention. During an armed conflict, the States involved in the conflict, as well as Neutral States, will typically continue to provide such air traffic services in relation to their flight information regions (FIR). ${ }^{15}$ The State providing air traffic services will in its flight information region "have a special responsibility for the safety of civil aircraft". ${ }^{16}$

2. The State responsible for providing air traffic services, should, based on the information that is available, "identify the geographical area of the conflict, assess the hazards or potential hazards to international civil aircraft operations, and

\footnotetext{
${ }^{15} \mathrm{~A}$ FIR is defined in the AMW Manual as "an aviation term used to describe airspace with specific dimensions, in which a flight information service and an alerting service are provided. Oceanic airspace is divided into Oceanic Information Regions and delegated to controlling authorities bordering that region. The division of authorities is done by international agreement through ICAO." See here Commentary on the AMW Manual, see chapter "Section I: Outer Space", fn. 1, page 239. See also Chicago Convention, fn. 2, Annex 2 Rules of the air, page 1-4.

${ }^{16}$ See 1990 Manual Concerning Safety Measures Relating to Military Activities Potentially Hazardous to Civil Aircraft Operations, ICAO Doc. 9554, page 14, para. 10.2.
} 
determine whether such operations in or through the area of conflict should be avoided or may be continued under specified conditions. An international Notice to Airmen (NOTAM) containing the necessary information, advice and safety measures to be taken should then be issued and subsequently updated in the light of developments." 17

3. A special problem occurs where such air traffic services are provided by an authority or entity located in a third State, as it might be difficult to gather sufficient information on the relevant risk levels in the foreign areas where it provides the said services. For instance, the Swiss company Skyguide-Swiss Air Navigation Services Limited-provides air traffic services for Switzerland, but also for adjoining areas in Germany, Austria, France and Italy. ${ }^{18}$ Should a non-international or international armed conflict take place in any of these areas beyond the Swiss borders, the authorities of the relevant territories may restrict or close their airspace although the airspace is normally handled by Skyguide. No such authority to close or restrict national airspace would seem to have been delegated to the company by the abovementioned States, but it is to be expected that the company will issue statements regarding the perceived threat level. Here, its potential responsibility for damage or destruction following insufficient warnings to civilian air traffic may presumably be reduced considering that it has less access to situational information on the current or planned military operations than would be the case for a national agency providing such services.

\section{Rule 95}

(a) During an armed conflict, States should-whenever necessary for the safety of civil aviation-restrict access to their national airspace (in whole or in part) by civilian airliners.

\section{Commentary}

1. See Rule 87 (a) with Commentary for general remarks on States' entitlement to restrict their national airspace. The present Rule is non-binding in character and concerned with situations when States should use their entitlement in this regard.

2. The failure of States to restrict access to their national airspace may contribute to tragic events such as the downing of Malaysia Airlines flight MH17 above Hrabove, Ukraine, on 17 July 2014.

\footnotetext{
${ }^{17} 1990$ Manual Concerning Safety Measures Relating to Military Activities Potentially Hazardous to Civil Aircraft Operations, see fn. 16, page 14, para. 10.3.

${ }^{18}$ See Skyguide, Annual Report 2015 (Geneva 2016) pages 22 and 28.
} 
3. The Chicago Convention Annexes 11, 15 and 17 place a due diligence obligation upon the State to ensure the safety of its airspace. ${ }^{19}$ Correspondingly, under Chicago Convention Annex 11, close cooperation must be established between air traffic services authorities and military authorities, and coordination of activities potentially hazardous to civil aircraft must also be established. ${ }^{20}$

4. Where a State has knowledge of a credible and concrete risk to airliners, and where restriction on the use or closure of its airspace is the only reasonable measure available, the State is obligated to act accordingly. Otherwise, a State is only obliged — at some indeterminate stage during the intensification of military activities in the airspace - to close parts of its airspace to foreign civil aviation. An alternative to prohibiting flights at all altitudes may be the prohibition against flying below a certain altitude. ${ }^{21}$

5. The Dutch Safety Board's consideration of States involved in NIACs shows that few States actually practice the closing (in whole or in part) of their airspace. ${ }^{22}$

6. Regardless of whether the territorial State decides to keep its airspace open, the State where the operator is registered may obligate the carrier not to use a specific foreign airspace or, at the very least, may place restrictions on the use of that airspace by its aircraft. ${ }^{23}$

\footnotetext{
${ }^{19}$ Chicago Convention, see fn. 2, Annex 11, Art. 2.17, Annex 15, Art. 5.1.1.1 (1) and (n), and Annex 17, Arts. 2.1.2, 2.4.3, and 3.1.3. Whether the Standards and Recommended Practices contained in annexes to the Chicago Convention are binding on the State parties is on the other hand disputed. For the ICAO view, see Res. A36-13 (2007) Consolidated statement of continuing ICAO policies and associated practices related specifically to air navigation. See as well statements by the ICAO Secretary General Raymond Benjamin in a letter to state civil authorities, 24 July 2014, page 2, para. 5 .

${ }^{20}$ Articles 2.17 and 2.18. See also Manual Concerning Safety Measures Relating to Military Activities Potentially Hazardous to Civil Aircraft Operations, see fn. 16.

${ }^{21}$ A slightly different view might be held by the Dutch Safety Board. See Dutch Safety Board, Crash of Malaysia Airlines flight MH17 Hrabove, Ukraine, 17 July 2014 (The Hague, October 2015) page 172. Here, the Manual Concerning Safety Measures Relating to Military Activities Potentially Hazardous to Civil Aircraft Operations, see fn. 11, para. 3.1.1 holds that "[i]n the event that a sudden outbreak of armed hostilities or any other factors preclude this normal co-ordination process, appropriate State and ATS authorities, civil aircraft operators and pilots-in-command of aircraft must assess the situation based on the information available and plan their actions so as not to jeopardize safety."

${ }^{22}$ Dutch Safety Board, Crash of Malaysia Airlines flight MH17 Hrabove, Ukraine, 17 July 2014 (The Hague, October 2015) pages 199-205 (Libya, Northern Mali and, after the MH17 incident, the Ukraine).

${ }^{23}$ Dutch Safety Board, Crash of Malaysia Airlines flight MH17 Hrabove, Ukraine, 17 July 2014 (The Hague, October 2015) pages 173-174, 221, 232 and 242.
} 
(b) A State must keep under review the level of danger to civil aviation under its air traffic control and inform the relevant foreign actors of any imminent dangers to aviation in the airspace for which it is responsible.

\section{Commentary}

1. The Group of Experts came to the conclusion that, as opposed to Rule 94 (a), the present Rule is binding upon States as an expression of customary international law. It appears that some States regard the general practice in this context as a matter of "best practice" rather than binding custom.

2. The Group of Experts was of the opinion that this duty is comparable to the duty of a coastal State to inform other States of a minefield in its territorial sea which poses imminent danger to shipping. ${ }^{24}$ It is, however, difficult to find State practice and opinio juris supporting an obligation to inform more generally on changes in the risk level during an armed conflict, ${ }^{25}$ although the non-binding ICAO Manual Concerning Safety Measures Relating to Military Activities Potentially Hazardous to Civil Aircraft Operations indicates that the territorial State should do this. ${ }^{26}$

\section{Rule 96 \\ Civilian airliners should avoid areas of potentially hazardous military activ- ity, even if civil aviation has not been restricted or prohibited in the respec- tive airspace.}

\footnotetext{
${ }^{24}$ The Corfu Channel Case, Judgment 9 April 1949, I.C.J. Reports 1949, pages 4-169, page 22: "The obligations incumbent upon the Albanian authorities consisted in notifying, for the benefit of shipping in general, the existence of a minefield in Albanian territorial waters and in warning the approaching British warships of the imminent danger to which the minefield exposed them. Such obligations are based, not on the Hague Convention of 1907, No. VIII, which is applicable in time of war, but on certain general and well-recognized principles, namely: elementary considerations of humanity, even more exacting in peace than in war; the principle of the freedom of maritime communication; and every State's obligation not to allow knowingly its territory to be used for acts contrary to the rights of other States." More generally, a coastal State is under an obligation to "give appropriate publicity to any danger to navigation, of which it has knowledge, within its territorial sea" according to UNCLOS, see chapter "Section IV: Unmanned Maritime Systems", fn. 1, Article $24(2)$.

${ }^{25}$ Dutch Safety Board, Crash of Malaysia Airlines flight MH17 Hrabove, Ukraine, 17 July 2014 (The Hague, October 2015) pages 207 and 262. The Dutch Safety Board report recommends on page 264 that ICAO member States "[e]nsure that States' responsibilities related to the safety of their airspace are more strictly defined in the Chicago Convention and the underlying Standards and Recommended Practices, so that it is clear in which cases the airspace should be closed."

${ }^{26} 1990$ Manual Concerning Safety Measures Relating to Military Activities Potentially Hazardous to Civil Aircraft Operations, see fn. 16, page 14, para. 10.3. See also Dutch Safety Board, Crash of Malaysia Airlines flight MH17 Hrabove, Ukraine, 17 July 2014 (The Hague, October 2015) pages 173 and 208-209. Chicago Convention, see fn. 2, Annex 15 Article. 5.1.1 here holds that "[a] NOTAM shall be originated and issued promptly whenever the information to be distributed is of a temporary nature and of short duration or when operationally significant permanent changes, or temporary changes of long duration are made at short notice, except for extensive text and/or graphics."
} 


\section{Commentary}

1. This Rule is based on Rule 54 of the AMW Manual and is a corollary non-binding Rule to the one applicable to States in Rule 95, in order to ensure the safety of civil aviation in time of armed conflict.

Open Access This chapter is licensed under the terms of the Creative Commons Attribution 4.0 International License (http://creativecommons.org/licenses/by/4.0/), which permits use, sharing, adaptation, distribution and reproduction in any medium or format, as long as you give appropriate credit to the original author(s) and the source, provide a link to the Creative Commons licence and indicate if changes were made.

The images or other third party material in this chapter are included in the chapter's Creative Commons licence, unless indicated otherwise in a credit line to the material. If material is not included in the chapter's Creative Commons licence and your intended use is not permitted by statutory regulation or exceeds the permitted use, you will need to obtain permission directly from the copyright holder. 